\title{
Effect of Biofertilizers and Levels of Sulphur on Growth and Yield attributes of Mustard [Brassica juncea (L.) Czern. \& Coss]
}

\author{
Jitendra Meena*, Vikram Singh, Sandeep Kumar and Abhishek Sagar
}

Department of Agronomy, Naini Agricultural Institute, Sam Higginbottom University of Agriculture, Technology \& Sciences, (Formerly Allahabad Agricultural Institute) Allahabad - 211007, Uttar Pradesh, India

*Corresponding author

\section{A B S T R A C T}

\begin{tabular}{|l|}
\hline Ke y w o r d s \\
Azotobacter, \\
mustard, PSB, \\
Sulphur
\end{tabular}

A field experiment was conducted during Rabi season of 2016-2017 at Crop Research Farm, Department of Agronomy, Naini Agricultural Institute, SHUATS, Allahabad, (U.P.), to study the " Effect of Biofertilizers and Levels of Sulphur on Growth and Yield of Mustard [Brassica juncea (L.) Czern. \& Coss]', It was consisting of combination of four levels of biofertilizer viz., Azotobacter, Phosphate Solubilizing Bacteria (PSB) and Azotobacter + Phosphate-Solubilizing bacteria with a control (no seed inoculation), and two levels of sulphur 20 and $40 \mathrm{~kg} \mathrm{ha}^{-1}$ with a control. This experiment includes 12 treatments which were laid out in Randomized Block Design with three replications. The experiment results revealed that the growth parameters such as plant height $(167.50 \mathrm{~cm})$, dry weight $(44.40 \mathrm{~g})$, number of branch plant ${ }^{-1}(6.80)$, yield attributes viz., number of siliqua plant ${ }^{-1}(291.20)$ and test weight (4.51 g) at $100 \mathrm{DAS}$, significantly recorded in treatment $\mathrm{T}_{12}$ with the application of Azotobacter + Phosphate Solubilizing bacteria +40 $\mathrm{kg} \mathrm{S} \mathrm{ha}{ }^{-1}$, as compared to control.

\section{Introduction}

Indian mustard [Brassica juncea (L.) Czern. \& Coss] belongs to the family Cruciferae (Brassicaceae) where, out of the three genera, Brassica is the most important one. It is mostly cultivated for oilseed and fodder and mustard crops are basically cultivated in temperate region. Mustard is the second important edible oilseed crop after soybean. Oilseeds play a vital role in Indian economy (Prasad, 2015). The oil and protein content of rapeseed-mustard crop is found to vary from 34.9 to $44.9 \%$ and 17.8 to $22.0 \%$ respectively.
The leaves of young plants are used as green vegetables, as they supply sulphur and minerals in the diet (Singh et al., 2012). Rapeseed-mustard group of crop is grown in more than 70 countries globally in an area of 36.15 million ha with a production of 71.09 million tonnes of seed and a productivity of $1,970 \mathrm{~kg} \mathrm{ha}^{-1}$ in 2013-14 (Vision-2050, ICARDRMR). India occupies the third position in area and production in world after Canada and China. In India, area, production and productivity of rapeseed-mustard was 5.76 million ha, 6.82 million tonnes and $1,184 \mathrm{~kg}$ $\mathrm{ha}^{-1}$, respectively in 2015-16. Rajasthan ranks 
first in area, followed by Haryana, Madhya Pradesh and Uttar Pradesh. As regard productivity, Haryana occupied the first position (GOI, 2016).

Agronomical achievements for increasing yield, use of chemical fertilizers has badly affected the soil microflora and soil health. Excessive use of nitrogenous fertilizers has reduced the natural availability of many micronutrients which are difficult to provide chemically (Anonymous, 2001). Biofertilizers have potential to solubilize / mobilize major nutrients such as nitrogen and phosphorus in addition to micronutrients and thus act as nutrient flow regulator in nature. Azotobacter is non-symbiotic nitrogen fixing agro-microbe having potential to fix considerable quantities of atmospheric nitrogen in the rhizosphere of non-legumes. Besides nitrogen fixation, Azotobacter inoculation may improve the crop productivity up to $25 \%$ over the control in the absence of any amendment and by $8.75 \%$ in the presence of NPK (Narula, 2000). Phosphate solubilizing bacteria (PSB) provides alternative biotechnology solution in sustainable agriculture to meet the $\mathrm{P}$ demand of the plant. These organisms in addition to providing $\mathrm{P}$ to the plants also facilitate plant growth by different mechanism (Dubey et al., 1997). Sulphur, now recognized as the $4^{\text {th }}$ major nutrient after nitrogen, phosphorus and potassium, is a constituent of three sulphur containing amino acids (cysteine, cystine and methionine), which are the building blocks of protein and about $90 \%$ of plant sulphur is present in these amino acids. Sulphur improves protein and oil content in seeds and is also associated with special metabolism in plant and the structural characteristics of protoplasm. Adequate supply of sulphur has been reported to enhance photosynthetic efficiency and productivity of Brassica genotypes (Ahmad and Abdin, 2000). Indian mustard markedly responded to sulphur fertilization in oilseeds. The chemical fertilizers being used for supplementing the major nutrient are generally either deficient or low in sulphur content.

\section{Materials and Methods}

The experiment was conducted during Rabi season 2016 at the Crop Research Farm, Department of Agronomy, Sam Higginbottom University of Agriculture, Technology and Sciences (SHUATS), Allahabad. The Crop Research Farm is situated at $25^{\circ} 57^{\prime} \mathrm{N}$ latitude, $87^{\circ} 19^{\prime} \mathrm{E}$ longitudes and at an altitude of $98 \mathrm{~m}$ above mean sea level. The soil of experimental plot was sandy loam in texture, neutral in soil reaction $(\mathrm{pH} 7.8)$, low in organic carbon $(0.38 \%)$, available $\mathrm{P}(19.50 \mathrm{~kg}$ $\mathrm{ha}^{-1}$ ), available $\mathrm{K}\left(173.04 \mathrm{~kg} \mathrm{ha}^{-1}\right)$ and $\mathrm{S}$ $(15.37 \mathrm{ppm})$. The treatments comprised of three types of biofertilizer viz., Azotobacter, Phosphate Solubilizing bacteria (PSB) and Azotobacter + Phosphate-Solubilizing bacteria with a control (no seed inoculation), and two levels of sulphur 20 and $40 \mathrm{~kg} \mathrm{ha}^{-1}$. There were 12 treatments each replicated thrice.

The experiment was laid out in Randomized Block Design. The seed was sown manually on 28 October 2016 by placing 2 seeds at a depth of 3-4 cm maintaining rows and plants spacing at $45 \times 15 \mathrm{~cm}$, respectively. Thinning was carried out 20 days after sowing to maintain required plant population. Irrigation was not found mandatory due to moderate rain at frequent intervals at initial stages of the crop but, after that 2 irrigations was given at 30 and 65 DAS. Phosphorus it is also applied as basal as per recommendation, whereas nitrogen was applied in 3 equal splits, viz., half as basal, one-fourth at first irrigations was given at 30 DAS and remaining one-fourth at initiation of second irrigations and in case of potassium it is also applied as basal as per recommendation. Plant height, number of branch plant ${ }^{-1}$, dry weight, number of siliquae plant $^{-1,}$ test weight, Yield viz., seed yield and 
stover yield likewise, quality parameters viz., oil content and oil yield were recorded and statistically analysed to find out the best treatment combination. In addition to yield and quality parameters, economics of treatments was also studied to find out the best treatment combination for higher yield, maximum net return and highest $\mathrm{B}$ : $\mathrm{C}$ ratio of mustard crop.

\section{Results and Discussion}

\section{Effect of growth parameter on mustard}

The data showed that (Table 1) there was a steady increase in plant height at 40, 60, 80 and 100 DAS, significantly higher value recorded was $84.60,131.78,159.44$ and167.50 $\mathrm{cm}$ in treatment $\mathrm{T}_{12}$ (Azotobacter + Phosphate Solubilizing bacteria $+40 \mathrm{~kg}$ Sulphur $\mathrm{ha}^{-1}$ ) respectively. The highest plant dry weight $(5.09 \mathrm{~g})$ at $40 \mathrm{DAS}$, recorded in treatment $\mathrm{T}_{12}$ Azotobacter + Phosphate Solubilizing bacteria $+40 \mathrm{~kg}$ Sulphur ha ${ }^{-1}$ though non-significant. However, treatment $\mathrm{T}_{12}$ Azotobacter + Phosphate Solubilizing bacteria $+40 \mathrm{~kg}$ Sulphur $\mathrm{ha}^{-1}$ recorded the significantly higher plant dry weight $12.06,28.07$ and $44.40 \mathrm{~g}$ at 60, 80 and 100 DAS respectively. A steady increase in number of branches plant ${ }^{-1}$ at 40 DAS, highest number of branches plant ${ }^{-1}$ (3.27) was recorded though non-significant difference among treatments.

However, treatment $\mathrm{T}_{12}$ Azotobacter + Phosphate Solubilizing bacteria $+40 \mathrm{~kg}$ Sulphur ha ${ }^{-1}$ recorded the significantly highest number of branches plant ${ }^{-1} 6.40,6.67$ and 6.80 at 60,80 and 100 DAS respectively. This might be due to increased availability of nutrients leading to high accumulation of net photo-synthetics with optimum dose of sulphur along with biofertilizers and availability of energy sources for prolonged time. Thus, better proliferation of roots and increased uptake of nutrients enhanced growth attributing characters (Meena et al., 2013). Similar findings were also reported by Mandal and Sinha (2002) and Shukla et al., (2002). Azotobacter which has the ability to fix nitrogen, produce plant growth promoting antifungal and antibacterial substances which influence plant growth favorably. Whereas, PSB improved the plant growth which might be due to solubilizing of native $P$ by phosphate-solubilizing microorganisms through production of organic acids like glutamice, sucinic, lactic, oxalic, glyoxalic, malic, fumaric, tartaric, propinic and formic (Mir et al., 2004).

There was influence of treatments on CGR at all the growth stages (Table 2). Treatment $\mathrm{T}_{12}$ Azotobacter + Phosphate Solubilizing bacteria $+40 \mathrm{~kg}$ Sulphur $\mathrm{ha}^{-1}$ observed that non significantly the highest crop growth rate (CGR) $3.45,11.86$ and $12.09 \mathrm{~g} \mathrm{~m}^{-2}$ day $^{-1}$ at 20-40, 60-80 and 80-100 DAS intervals. However, significantly the highest (CGR) 5.17 $\mathrm{gm}^{-2}$ day $^{-1}$ at $40-60$ DAS intervals. The relative growth rate different treatments observed that non significantly the highest relative growth rate (RGR) $0.13,0.05$ and 0.05 $\mathrm{g} \mathrm{g}^{-1}$ day $^{-1}$ at 20-40, 40-60 and 60-80 DAS interval.

Further, at 80-100 DAS interval the exact same value of relative growth rate $\left(0.02 \mathrm{~g} \mathrm{~g}^{-1}\right.$ day $^{-1}$ ) was registered in all the treatments. The higher crop growth rate among the biofertilizers might be due to higher dry matter accumulation. Since the CGR is a function of total dry matter production (Pramanik and Bera, 2013). This result is in full agreement with Shinde (1990). The reason for obtaining higher relative growth rate may be due to increase in cell multiplication, cell elongation and cell expansion throughout the entire period of crop. This might be resulted in higher production of photosynthetics and their translocation to sink, which ultimately increased the plant growths. 
Table.1 Effect of biofertilizers and levels of sulphur on growth parameters of mustard

\begin{tabular}{|c|c|c|c|c|c|c|c|c|c|c|c|c|c|}
\hline & \multirow[t]{2}{*}{ Treatments } & \multicolumn{4}{|c|}{ Plant height (cm) } & \multicolumn{4}{|c|}{ Plant dry weight (g) } & \multicolumn{4}{|c|}{ Number of branches plant $t^{-1}$} \\
\hline & & $\begin{array}{c}40 \\
\text { DAS }\end{array}$ & $\begin{array}{c}60 \\
\text { DAS }\end{array}$ & $\begin{array}{c}80 \\
\text { DAS }\end{array}$ & $\begin{array}{c}100 \\
\text { DAS }\end{array}$ & $\begin{array}{c}40 \\
\text { DAS }\end{array}$ & $\begin{array}{c}60 \\
\text { DAS }\end{array}$ & $\begin{array}{c}80 \\
\text { DAS }\end{array}$ & $\begin{array}{c}100 \\
\text { DAS }\end{array}$ & $\begin{array}{c}40 \\
\text { DAS }\end{array}$ & $\begin{array}{c}60 \\
\text { DAS }\end{array}$ & $\begin{array}{c}80 \\
\text { DAS }\end{array}$ & $\begin{array}{c}100 \\
\text { DAS }\end{array}$ \\
\hline $\mathrm{T}_{1}$ & Control & 73.51 & 120.98 & 145.37 & 149.42 & 3.77 & 7.93 & 20.81 & 34.11 & 2.73 & 4.33 & 4.87 & 5.00 \\
\hline $\mathrm{T}_{2}$ & Control + $20 \mathrm{~kg} \mathrm{~S} \mathrm{ha}^{-1}$ & 76.30 & 124.23 & 149.22 & 154.65 & 3.86 & 9.05 & 22.57 & 36.50 & 2.80 & 4.87 & 5.33 & 5.40 \\
\hline $\mathrm{T}_{3}$ & Control + $40 \mathrm{~kg} \mathrm{~S} \mathrm{ha}^{-1}$ & 80.85 & 126.91 & 152.45 & 158.42 & 4.17 & 10.11 & 25.20 & 39.71 & 3.00 & 5.60 & 6.00 & 6.07 \\
\hline $\mathrm{T}_{4}$ & Azotobacter $+0 \mathrm{~kg} \mathrm{~S} \mathrm{ha}^{-1}$ & 75.36 & 123.48 & 146.68 & 153.14 & 3.89 & 8.78 & 22.06 & 35.54 & 2.87 & 4.53 & 5.07 & 5.13 \\
\hline $\mathrm{T}_{5}$ & Azotobacter $+20 \mathrm{~kg} \mathrm{~S} \mathrm{ha}^{-1}$ & 80.20 & 127.12 & 150.62 & 157.73 & 4.28 & 9.52 & 23.89 & 38.40 & 2.93 & 5.40 & 5.93 & 6.00 \\
\hline $\mathrm{T}_{6}$ & Azotobacter $+40 \mathrm{~kg} \mathrm{~S}^{-1}$ & 82.27 & 128.33 & 156.12 & 163.97 & 4.31 & 11.25 & 26.44 & 42.08 & 3.00 & 6.13 & 6.40 & 6.47 \\
\hline $\mathrm{T}_{7}$ & P S B + $0 \mathrm{~kg} \mathrm{~S} \mathrm{ha}^{-1}$ & 77.32 & 125.05 & 148.51 & 156.16 & 3.97 & 9.09 & 23.35 & 37.67 & 2.93 & 4.80 & 5.87 & 5.93 \\
\hline $\mathrm{T}_{8}$ & P S B + $20 \mathrm{~kg} \mathrm{Sha}^{-1}$ & 81.15 & 127.75 & 154.84 & 162.62 & 4.39 & 11.12 & 25.79 & 41.18 & 3.07 & 5.93 & 6.13 & 6.20 \\
\hline $\mathrm{T}_{9}$ & P S B + $40 \mathrm{~kg} \mathrm{~S} \mathrm{ha}^{-1}$ & 83.13 & 130.21 & 157.31 & 165.28 & 4.72 & 11.33 & 27.11 & 43.31 & 3.20 & 6.27 & 6.53 & 6.60 \\
\hline $\mathrm{T}_{10}$ & Azotobacter + P S B $+0 \mathrm{~kg} \mathrm{~S} \mathrm{ha}^{-1}$ & 79.87 & 126.06 & 151.50 & 157.19 & 4.01 & 10.27 & 24.70 & 39.77 & 2.87 & 5.80 & 6.00 & 6.13 \\
\hline $\mathrm{T}_{11}$ & Azotobacter + P S B $+20 \mathrm{~kg} \mathrm{~S} \mathrm{ha}^{-1}$ & 81.56 & 128.00 & 155.62 & 163.12 & 4.36 & 11.20 & 26.21 & 42.39 & 3.13 & 6.07 & 6.27 & 6.33 \\
\hline \multirow[t]{3}{*}{$\mathrm{T}_{12}$} & Azotobacter + P S B $+40 \mathrm{~kg} \mathrm{~S} \mathrm{ha}^{-1}$ & 84.60 & 131.78 & 159.44 & 167.50 & 5.09 & 12.06 & 28.07 & 44.40 & 3.27 & 6.40 & 6.67 & 6.80 \\
\hline & SEd $( \pm)$ & 2.17 & 2.27 & 2.32 & 2.48 & 0.37 & 0.51 & 1.03 & 1.18 & 0.16 & 0.23 & 0.25 & 0.27 \\
\hline & $\mathrm{CD}(\mathrm{P}=0.05)$ & 4.50 & 4.71 & 4.81 & 5.13 & - & 1.07 & 2.13 & 2.44 & - & 0.47 & 0.53 & 0.57 \\
\hline
\end{tabular}


Table.2 Effect of biofertilizers and levels of sulphur on growth parameters of mustard

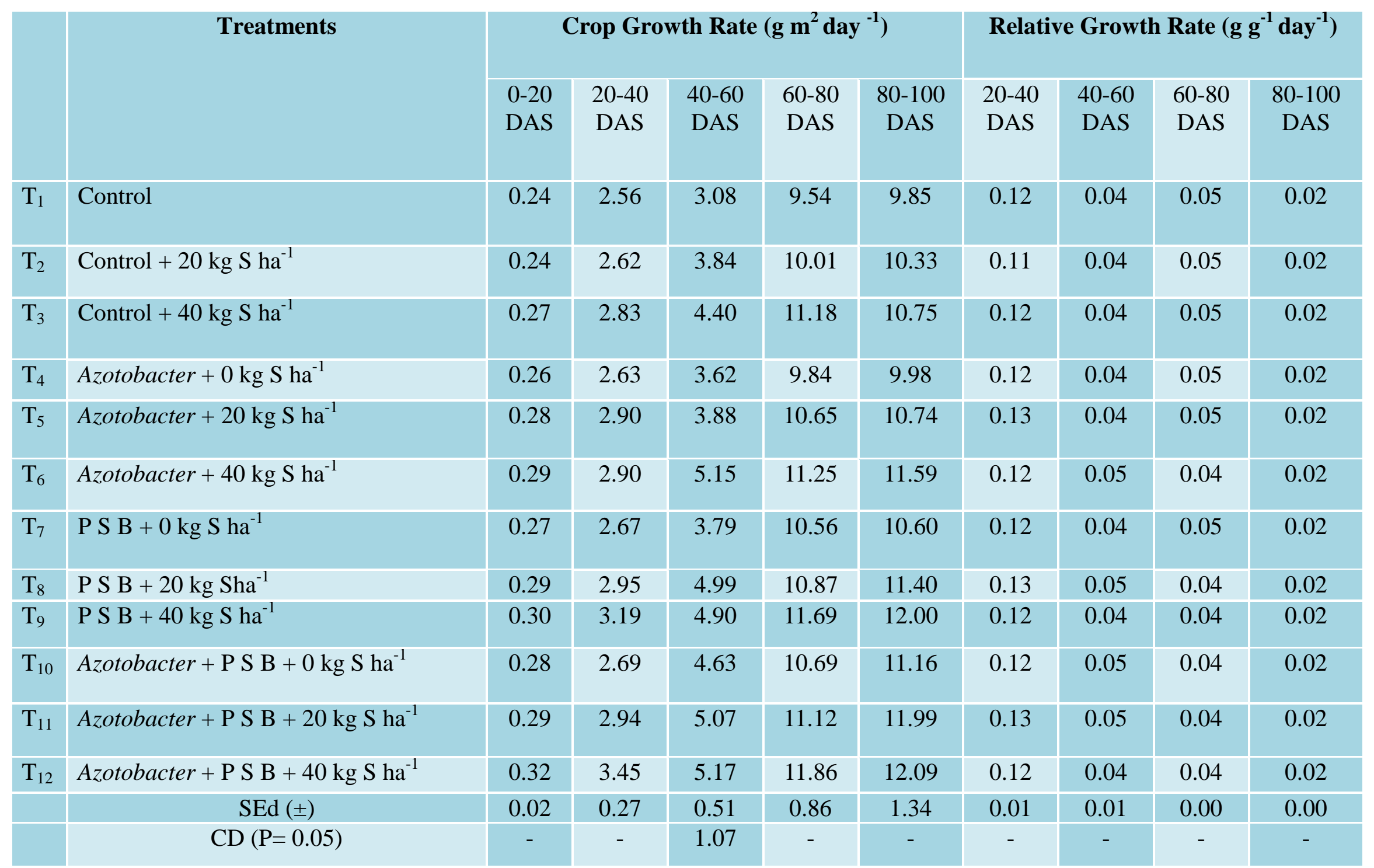


Table.3 Effect of biofertilizers and levels of sulphur on yield attributes of mustard

\begin{tabular}{|c|c|c|c|c|c|}
\hline & Treatments & $\begin{array}{c}\text { Length of } \\
\text { siliqua }(\mathrm{cm})\end{array}$ & $\begin{array}{c}\text { Number of siliqua } \\
\text { plant }^{-1}\end{array}$ & $\begin{array}{c}\text { Number of } \\
\text { seeds siliqua }^{-1}\end{array}$ & Test weight (g) \\
\hline $\mathrm{T}_{1}$ & Control & 4.48 & 226.74 & 13.40 & 3.86 \\
\hline $\mathrm{T}_{2}$ & Control + $20 \mathrm{~kg} \mathrm{~S} \mathrm{ha}^{-1}$ & 4.81 & 247.51 & 13.67 & 3.99 \\
\hline $\mathrm{T}_{3}$ & Control + $40 \mathrm{~kg} \mathrm{~S} \mathrm{ha}^{-1}$ & 5.09 & 259.73 & 14.13 & 4.24 \\
\hline $\mathrm{T}_{4}$ & Azotobacter $+0 \mathrm{~kg} \mathrm{~S} \mathrm{ha}^{-1}$ & 4.75 & 241.84 & 13.67 & 3.90 \\
\hline $\mathrm{T}_{5}$ & Azotobacter $+20 \mathrm{~kg} \mathrm{~S} \mathrm{ha}^{-1}$ & 4.90 & 255.34 & 14.07 & 4.23 \\
\hline $\mathrm{T}_{6}$ & Azotobacter $+40 \mathrm{~kg} \mathrm{~S} \mathrm{ha}^{-1}$ & 5.13 & 273.30 & 14.60 & 4.37 \\
\hline $\mathrm{T}_{7}$ & P S B + $0 \mathrm{~kg} \mathrm{~S} \mathrm{ha}{ }^{-1}$ & 4.88 & 252.67 & 13.93 & 3.96 \\
\hline $\mathrm{T}_{8}$ & P S B + $20 \mathrm{~kg} \mathrm{Sha}^{-1}$ & 5.07 & 267.71 & 14.53 & 4.25 \\
\hline $\mathrm{T}_{9}$ & P S B + $40 \mathrm{~kg} \mathrm{~S} \mathrm{ha}^{-1}$ & 5.18 & 288.33 & 15.00 & 4.43 \\
\hline $\mathrm{T}_{10}$ & Azotobacter + P S B + $0 \mathrm{~kg} \mathrm{~S} \mathrm{ha}^{-1}$ & 4.96 & 262.47 & 14.40 & 4.17 \\
\hline $\mathrm{T}_{11}$ & Azotobacter + P S B $+20 \mathrm{~kg} \mathrm{~S} \mathrm{ha}^{-1}$ & 4.87 & 272.14 & 14.13 & 4.36 \\
\hline \multirow[t]{3}{*}{$\mathrm{T}_{12}$} & Azotobacter + P S B + $40 \mathrm{~kg} \mathrm{~S} \mathrm{ha}^{-1}$ & 5.26 & 291.20 & 15.07 & 4.51 \\
\hline & $\operatorname{SEd}( \pm)$ & 0.28 & 6.71 & 0.52 & 0.15 \\
\hline & $\mathrm{CD}(\mathrm{P}=0.05)$ & - & 13.92 & - & 0.32 \\
\hline
\end{tabular}




\section{Effect of yield attributes on mustard}

The data showed that (Table 2) higher length of siliquae and number of seeds siliqua ${ }^{-1} 5.26$ (cm) and 15.07 were found in treatment $\mathrm{T}_{12}$ Azotobacter + Phosphate Solubilizing bacteria $+40 \mathrm{~kg}$ Sulphur ha ${ }^{-1}$ though non-significant, which was $17.41 \%$ and $12.46 \%$ higher compared to the lowest value of 4.48 and 13.40 observed in treatment $\mathrm{T}_{1}$ Control.

A significant difference within the treatments for number of siliqua plant ${ }^{-1}$ and test weight 291.20 and 4.51 were recorded significantly higher under the treatment $\mathrm{T}_{12}$ Azotobacter + Phosphate Solubilizing bacteria $+40 \mathrm{~kg}$ Sulphur ha ${ }^{-1}$ respectively. Whereas, significantly lower number of siliquae plant $^{-1}$ (226.74) and lower test weight (3.86) were observed under $\mathrm{T}_{1}$ (control) respectively.

This might be due to the fact that Azotobacter inoculation fixed atmospheric nitrogen into soil asymbiotically results into better root development and more nutrient availability, resulted in better flowering and siliqua formation and ultimately beneficial effect on seed yield. There were to be a positive synergistic effects that caused to improving photosynthesis by increasing water and nutrients absorption and thus leading to more assimilate and improving plant growth, as result number of siliquae plant ${ }^{-1}$ and 1,000 seed weight may have increased as compared with Azotobacter, PSB + Azotobacter inoculation (Pramanik and Bera, 2013). Similar result was reported by Barea et al., (1975).

The increase in yield attributes with sulphur may be ascribed to its role in the synthesis of protein, oil and vitamins (Table 3). Application of sulphur may have helped in improvement in yield attributes of Indian mustard (Piri and Sharma 2006). These results the findings of Chauhan et al., (1996)

\section{References}

Ahmad, A. and Abdin, M.Z. 2000. Photosynthesis and its related physiological variables in the leaves of Brassica genotypes as influenced by sulphur fertilization. Physiologia Planetarium. 110: 144-9.

Anonymous (2001). In: Biofertilisers (A Training Manual). Regional Biofertiliser Development Centre, Imphal Mnipur.

Brar, A.S., Sidhu, P.S. and Dhillon, G.S. 2016. Response of brown sarson (Brassica campestris var. brown sarson) to integrated nutrient management in mid hill conditions of Himachal Pradesh. International J. Agric. Sci., 12(2): 319-325.

Dubey, A.V., Vaishya, U.K., Bapat, P.N. and Tomar, V.S. 1997. Microbial solubilization of rock phosphate: an alternative phosphorus source for mustard crop. JNKVV Research Journal 31(1-2): 54-55.

GOI. 2016. Agricultural statistics at a glance: Ministry of Agriculture \& Farmers Welfare Department of Agriculture, Cooperation \& Farmers Welfare Directorate of Economics \& Statistics New Delhi

Mandal, K.G. and Sinha, A.C. 2002. Effect of integrated nutrient management on growth, yield, oil content and nutrient uptake of Indian mustard (Brassica juncea) in foot hill soils of Eastern India. Indian Journal of Agronomy 47(1): 109-13.

Meena, D.S., Tetarwal, J.P. and Ram Baldev, 2013. Effect of chemical and biofertilizers on productivity, profitability and quality of Indian mustard (Brassica juncea) in Vertisols. Indian Journal of Agronomy; 58(1):96-99.

Mir, A.H., Hayat, S. and Ahmad, I. 2004. Performance of biofertilizer inoculation 
to Indian mustard. Field Crop Abstr. 57: 654- 55 .

Narula, Neeru 2000. Azotobactor as an organism. (In:) Azotobactor in Sustainable Agriculture. Neeru Narula Ed. CBS Publishers and Distributors, New Delhi: pp. 1-12.

Piri, I. and Sharma, S.N. 2006. Effect of levels and sources of sulphur on yield attributes, yield and quality of Indian mustard (Brassica juncea). Indian Journal of Agronomy 51(3): 217-220.

Pramanik, K. and Bera, A.K. 2013. Effect of biofertilizers and phytohormone on growth, productivity and quality of sunflower (Helianthus annuus L.) Journal of Crop and Weed 9(2):122-127

Prasad, R. 2015. Txtbook of field crops production-commercial crops volume II. Directorate of Knowledge Management in Agriculture, Indian Council of Agricultural Research. Krishi Anusandhan Bhawan 1, Pusa, New Delhi 110012.
Shinde, V.S. 1990. Response of chickpea (Cicer arietinum L.) to phosphorus with and without PSB (Microphos) as influenced by applied sulphur. Ph.D. Thesis, Division of Agronomy, IARI. New Delhi.

Shukla, R.K., Kumar, A., Mahapatra, B.S. and Kandpal, B. 2002. Integrated nutrient management practices in relation to morphological and physiological determinants of seed yield in Indian mustard (Brassica juncea). Indian J. Agril. Sci. 72(11): 670-672.

Singh, C., Singh, P. and Rajbir, S. 2012. Oil crops of mustard (Brassica juncea L.) Genaral Introduction. Modern Techniques of Raising Field Crops. Oxford \& IBH Publishing Company Pvt. Ltd. New Delhi. p. 337-354.

Vision-2050, ICAR-DRMR 2015. Directorate of Rapeseed-Mustard Research (Indian Council of Agricultural Research) Sewar, Bharatpur $321 \quad 303$ www.drmr.res.in

\section{How to cite this article:}

Jitendra Meena, Vikram Singh, Sandeep Kumar and Abhishek Sagar. 2018. Effect of Biofertilizers and Levels of Sulphur on Growth and Yield attributes of Mustard [Brassica juncea (L.) Czern. \& Coss]. Int.J.Curr.Microbiol.App.Sci. 7(10): 2242-2249. doi: https://doi.org/10.20546/ijcmas.2018.710.258 